\title{
Strontium Beta-Irradiation: Can it Prove Strong Enough in Curbing the Ophthalmic Hydra Called Pterygium
}

\section{Abhishek Onkar ${ }^{1 *}$, Saurabh Samdariya ${ }^{2}$, Puneet Pareek ${ }^{2}$ and Suwarna Suman ${ }^{1}$}

${ }^{1}$ Department of Ophthalmology, AlIMS Jodhpur, India

${ }^{2}$ Department of Radiation Oncology, AlIMS Jodhpur, India

\begin{abstract}
No other ophthalmic disorder, or may be any medical disorder, has elicited so much interest as pterygium. Even though eons have passed since it was first discovered, its propensity for regrowth like tentacles of hydra, continue to perplex the ophthalmic community. Its propensity for recurrences has attracted all and the sundry and newer modalities are being propounded to prevent recurrences. This article reviews the role of radiation therapy for recurrence prevention in pterygium management.
\end{abstract}

Keywords: Strontium beta-irradiation; Ophthalmic; Pterygium; Radiation therapy

\section{Introduction}

Etymologically derived from the Greek word 'pterygion' meaning small wing, pterygium has been in vogue since the times of Sushruta (6th century B.C.). It is a triangular, wing-like fibro-vascular encroachment of degenerative sub-epithelial conjunctiva, straddling the limbus, onto the cornea (Figure 1). Pterygium, with a prevalence of 0.3 to $29 \%$, is common in the 'pterygium belt' lying $37^{\circ}$ on either side of equator [1,2]. Chronic exposure to ultra-violet $\mathrm{B}$ radiations, limbal stem cell deficiency, human papilloma virus infection, p53 gene mutations and imbalance of matrix metalloproteinases (MMP) and tissue inhibitors of metalloproteinases (TIMP) have been strongly implicated in pterygium causation [3]. Whereas diagnosis and management of primary pterygium is an iotic task, managing recurrences is a titanic one.

\section{Discussion}

While primary pterygium excision with conjunctival graft remains the standard procedure for prevention of recurrences with recurrence rate of $2-35 \%$, many other methodologies have been used with varying degree of success. Intra-operative and post-operative mitomycin-C (0.01-0.04\%) with recurrence rate of $3-38 \%$ is another very commonly used modality $[4,5]$.

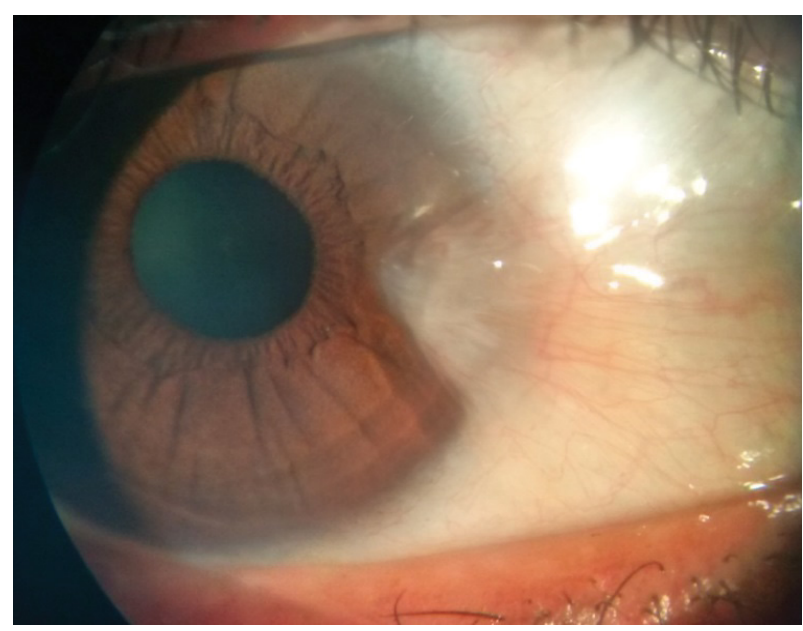

Figure 1: Pterygium in a 17 year old male.
Intra-operative Doxorubicin (0.02\%), daunoribicin (0.02\%), cyclosporine A $(0.1 \%)$ eye-drops, thiotepa $(0.05 \%)$ eye-drops and 5 -fluoro-uracil $(5 \%)$ are the other medical options shown to have promising results in recurrence prevention in various studies. Off-late, sub-conjunctival anti-VEGF Bevacizumab (1.25-2 mg) therapy has also been proposed for the aforesaid. All these agents are associated with risk of serious complications like scleral perforations, scleritis, scleral necrosis, and endophthalmitis (Figure 2).

\section{Role of beta-irradiation}

The standard technique is a strontium (Sr90) brachytherapy with an epibulbar plaque which has central radioactive disc and non- active rim of $2 \mathrm{~mm}$ (Figure 3 ).

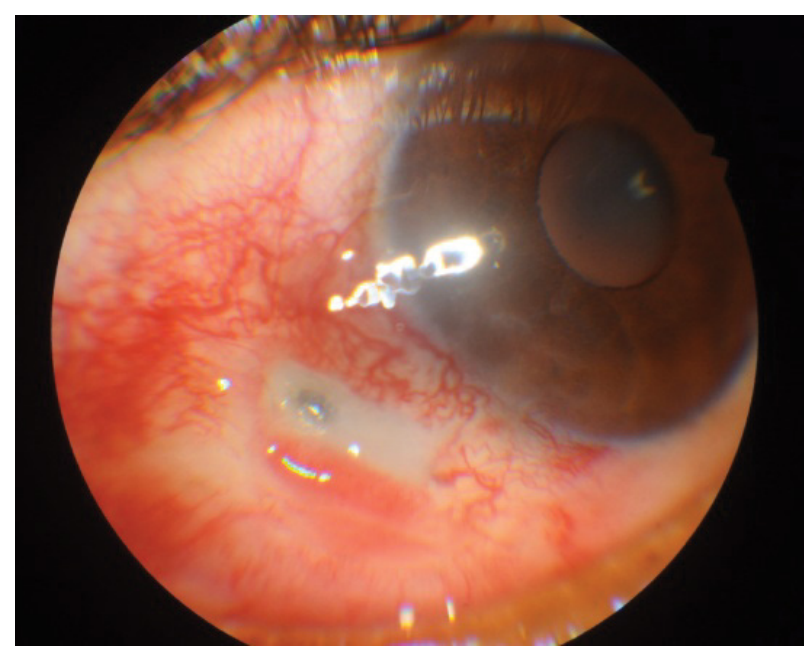

Figure 2: Scleral perforation secondary to mitomycin-C application intraoperatively.

*Corresponding author: Dr. Abhishek Onkar, 402 Belita, Arihant Adita, Gangana Pal Road, Near Lady Pillar Convent School, Jodhpur, Rajasthan-342014, India, Tel: 91-9871984534; E-mail: onkaratdmch@gmail.com

Received June 07, 2017; Accepted June 26, 2017; Published July 02, 2017

Citation: Onkar A, Samdariya S, Pareek P, Suman S (2017) Strontium BetaIrradiation: Can it Prove Strong Enough in Curbing the Ophthalmic Hydra Called Pterygium. Surgery Curr Res 7: 298. doi: 10.4172/2161-1076.1000298

Copyright: ( 2017 Onkar A, et al. This is an open-access article distributed under the terms of the Creative Commons Attribution License, which permits unrestricted use, distribution, and reproduction in any medium, provided the original author and source are credited. 


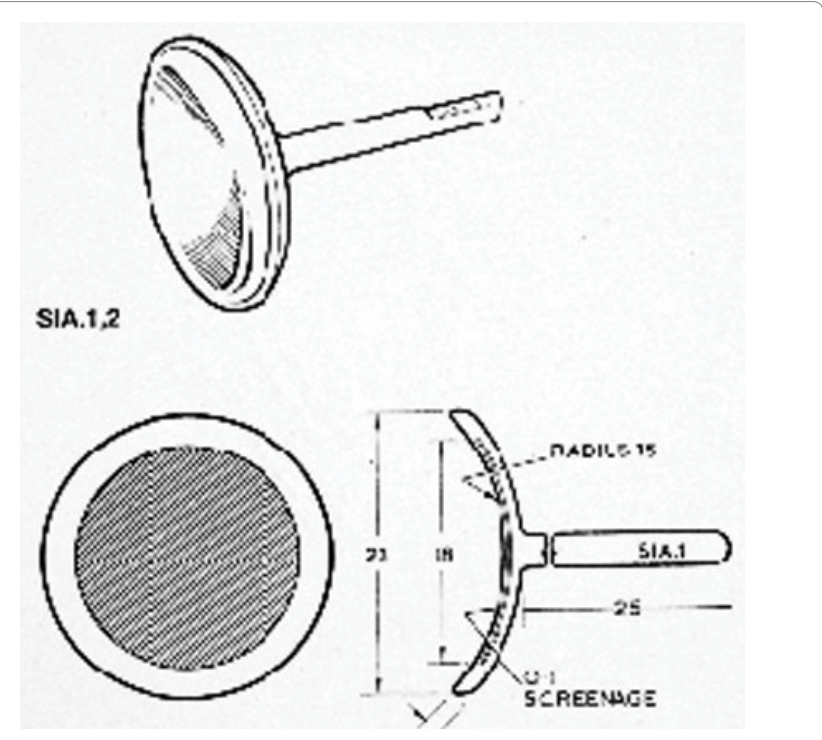

Figure 3: SR-90 Epibulbar applicator.

A total dose of $25-60$ Gy is to be delivered in 1-6 fractions at a rate of $5-20 \mathrm{~Gy} / \mathrm{min}$. Most commonly, a dose of $30 \mathrm{~Gy}$ is delivered in 3 weekly fractions of $10 \mathrm{~Gy}$ with the first application being administered intra-operatively or at least within 48 hours after surgery.

Regimes of beta-irradiation advocated for recurrence prevention are

- Single application of beta-irradiation.

- Multiple applications over consecutive days immediately in postop period.

- Multiple applications over a 2-week period.

Cumbersome instrumentation and inconvenience of arranging its treatment account for the limited utility of this modality although the recurrence rates are comparable to post-operative mitomycin- $\mathrm{C}$ application [6].

Conjunctival auto-grafting and mitomycin- $\mathrm{C}$ are being used by all and the sundry, undermining the role of beta radiation. Though conjunctival auto grafting is considered the safest and most effective, it is time consuming. Time factor becomes very pertinent in developing countries where patient to ophthalmologist ratio is negatively skewed, incidence of pterygium is high and potentially blinding diseases account for the bulk of surgical time. Comparative data for beta radiation and mitomycin $\mathrm{C}$ are conflicting with Amano et al. suggesting superiority of mitomycin- $\mathrm{C}$ while Snibson et al. and Simsek et al. giving verdict in favour of beta irradiation [7-10].

\section{Conclusion}

Pterygium surgery has infallibly evolved over the years. Still the quest for an ideal recurrence free modality of pterygium management remains evasive and futile. This highlights the need to have a better understanding of the aetio-pathogenesis of pterygium as well as its recurrence. Also, treatment plan should be customized for each case rather than blindly following a single technique. Ironically, though 'pterygium' means a 'small wing', over the centuries its wings have expanded beyond our understanding and imagination. This triangular enigma can truly be called the 'Bermuda triangle' of ophthalmology as it continues to baffle us all. A concerted effort on our part is required to solve this mystery and Beta irradiation could prove to be the guiding light.

\section{References}

1. Cameron ME (1962) Geographic distribution of pterygia. Trans Ophthalmol Soc Aust 22: 67-81.

2. Taylor HR, West SK, Rosenthal FS, Munoz BM, Newland HS, et al. (1989) Corneal changes associated with chronic UV irradiation. Arch Ophthalmol 107: $1481-1484$.

3. Di Girolamo N, Chui J, Coroneo MT, Wakefield D (2004) Pathogenesis of pterygia: Role of cytokines, growth factors, and matrix metalloproteinases. Prog Retin Eye Res 23: 195-228.

4. Rocha G (2003) Surgical management of pterygium. Techniques in Ophthalmology 1: 22-28.

5. Cardillo JA, Alves MR, Ambrosio LE, Poterio MB, Jose NK (1995) Single intraoperative application versus postoperative mitomycin $C$ eye drops in pterygium surgery. Ophthalmology 102: 1949-1952.

6. Nishimura Y, Nakai A, Yoshimasu T, Yagyu Y, Nakamatsu K, et al. (2000) Long term results of fractionated strontium 90 radiation therapy for pterygia. Int $J$ Radiat Oncol Biol Phys 46: 137-141.

7. de Keizer RJ (1997) Pterygium excision with free conjunctival autograft (FCG) versus postoperative strontium $90(90 \mathrm{Sr})$ beta irradiation. A prospective study. Int Ophthalmol 21: 335-341.

8. Amano S, Motoyama Y, Oshika T, Eguchi S, Eguchi K (2000) Comparative study of intraoperative mitomycin $\mathrm{C}$ and beta irradiation in pterygium surgery. Br J Ophthalmol 84: 618-621.

9. Snibson GR, Luu CD, McKenzie JD, Taylor HR (1996) A prospective randomized controlled trial of beta radiation, mitomycin $C$, and conjunctival transplantation in the surgical management of pterygium. Invest Ophthalmo Vis Sci 37: 703.

10. Simsek T, Gunalp I, Atilla $\mathrm{H}$ (2001) Comparative efficacy of betairradiation and mitomycin $\mathrm{C}$ in primary and recurrent pterygium. Eur J Ophthalmol 11: 126-132. 